\title{
Investigating possibilities to integrate solar heat into district heating systems of Lithuanian towns
}

\author{
Vaclovas Kveselis, Aurimas Lisauskas, Eugenija Farida Dzenajavičienè \\ Lithuanian Energy Institute, Breslaujos str. 3, LT-44403 Kaunas, Lithuania
}

\begin{abstract}
Lithuanian district heating sector is one having ambitious targets while implementing national energy policy goals. It is strongly orientated towards extending usage of renewables, basically biomass. Notwithstanding with this, other renewable sources can also play important role following the experience of other countries. Solar energy is one of emerging options rapidly developing in Scandinavia, Germany, Austria and Netherlands. Use of on-roof and on-ground collectors together with short term and seasonal storage facilities allows usage of solar energy from solar collectors both: for reduction of heat losses in the networks as well as for providing significant share of heat without fuel burning. Economic feasibility as well as technical behavior of different types of seasonal heat storages is still under investigation, however fast development of technologies might prove this solution as feasible opportunity in nearest future. The cost of solar heat depends mainly on capital investment to the solar collectors and storage, as fuel costs are zero and maintenance costs are insignificant. Therefore investment support is crucial for feasibility and competitiveness of such systems. From the technical point of view, temperature level is very significant factor for efficient functioning of solar heating systems. This point is worth to address in complex with building's heating system and heat supply network renovation.
\end{abstract}

Keywords: District heating, solar energy, heat storages.

\section{Background}

Possibility to use solar energy for heating and cooling needs were first defined immediately after the first oil crisis, when the Solar Heating and Cooling Program was established in 1977 by IEA. It was then already considered that solar energy could replace fossil fuels in many applications. Key applications for solar technologies are those requiring low temperature heats, such as domestic hot water, space heating, drying processes, water processes for industrial heating and swimming pools [1].

Initially solar energy was mainly used for electricity generation in the regions with extensive energy radiation, like Mediterranean region in order to significantly develop the identified solar projects [2]. Later it was investigated that renewable resources can contribute to a major share of the overall energy supply which strongly conditions the overall primary energy balance. The choice and sizing of the heating system can significantly affect the overall primary energy balance, depending on the share of heating load in the overall energy needs [3]. Individually heated buildings are converted to use heat pumps, supplemented by solar thermal collectors [4].

Further development of solar heating was introduction of low-energy buildings concept, while buildings could completely remove the need for heating or even, by the use of e.g. solar thermal energy, be plus energy houses producing more heat than they demand.

Assessment of current solar heating and cooling (SHC) situation shows that SHC being straightforward application of renewable energy is already widely used for domestic hot water heating in a number of countries but on a global level contributes to $0.4 \%$ only of energy demand for domestic hot water. SHC also includes technologies for other purposes such as space heating, space cooling and hot water for industrial processes. As different SHC technologies are at widely differing stages of development and use, policy support must offer custom-made solutions [5].

A potential of up to 4 million $\mathrm{m}^{2}$ of large-scale solar heating panels for district heating was identified, which will be competitive and can produce heat at around 20 per cent of the cost of individual solar heating panels [6]. A hightemperature heat flux is used as driving force to recover the low-temperature heat flux from an ambient heat source, including solar heat and geothermal heat [7]. The existence of potential for better energy utilization through introducing

Corresponding author: Eugenija Farida Dzenajavičienė. E-mail address: vkv@mail.lei.lt

http://dx.doi.org/10.3846/enviro.2014.268

(C) 2014 The Authors. Published by VGTU Press. This is an open-access article distributed under the terms of the Creative Commons Attribution License, which permits unrestricted use, distribution, and reproduction in any medium, provided the original author and source are credited. 
more cascading in the design or trying to partially meet the low temperature heating demands of the residential sector by using lower quality heat sources such as solar collectors was investigated in [8].

Integration of solar thermal systems into district heating networks is currently the priority task for solar energy. The possible solar thermal contribution currently is very low at $0.3 \%$ of the total heat demand. The RR-assisted* option with $421 \mathrm{kWh} / \mathrm{m}^{2}$ a specific solar gain is energetically the most effective strategy to integrate solar thermal collectors into a DH network. The extension of the solar collectors' area and use of the storage allows achieving $100 \%$ solar fraction during the summer [9]. Large solar thermal systems have proven to be cost effective in cases of combining a large solar system with long term storage. Also, heat pumps seem to be attractive in an efficient modern energy system due to flexibility when supplying combined heat and power production in a liberal market for electricity and realizing potential for obtaining very high solar and renewable fractions of supply [10].

First solar heat applications in district heating systems were initiated in Denmark, Sweden, Germany, Austria and Netherlands with first investigations of impact achieved. Large-scale solar thermal applications corresponding to app. 11\% of the DH production in Denmark was considered as biomass demand reducing technology. With the existing thermal heat storages, $5 \%$ of the DH demand (including net losses) in $50 \%$ of DH areas with large central CHP plants can be produced with solar thermal. With $8 \mathrm{GWh}$ of extra thermal heat storage $50 \%$ for the decentralized small CHP plants, $25 \%$ solar thermal can be implemented corresponding to $1.39 \mathrm{TWh}$. Currently about $20 \mathrm{GWh}$ of thermal heat storage is installed in small CHP. In areas that do not currently have CHP but supply heat with boilers, $50 \%$ of the DH demand can be covered with solar thermal in $90 \%$ of these plants areas, corresponding to $80 \mathrm{GWh}$ as long-term heat storages. Here an hourly loss of $0.01 \%$ is included [11].

However, large solar district heating systems still appear to be rather expensive and need extensive support measures. A range of support measures for renewable thermal energy, including solar thermal options, such as grants, tariffs or bonuses, tax related mechanisms, support for research, development and demonstration, use obligations were investigated [12]. These measures are most extensively developed in Germany. Renewable Energies Heat Act and grants program MAP (Germany) provide important incentives with long-term prospects for expanding the use of renewable energy. For solar collectors, the development of the new and potentially very profitable market segment of large solar systems is included. Affecting the entire heat market, the structural changes towards more district heat is favored in part by financial incentives (MAP) and in part by providing additional legal instruments to the municipalities [13].

In year 2012 the new project "Solar District Heating" (SDH plus), partly funded by EU Program Intelligent Energy for Europe was launched to foster development of solar heat in DH systems. It provides a large amount of theoretical, technical and economic as well as good practice examples, which should provide background for wider range of countries [14]. Lithuanian energy institute is among project partners.

\section{Aim and scope of the investigation}

At present research was initiated to justify the use of solar energy for space heating. However such recommendations are still being elaborated and there are no actual operating space heating systems in Lithuania. In the National Energy Efficiency Program the potential to use solar energy for heating needs is assessed with assumption that solar energy will cover $10 \%$ of heating and approximately $30 \%$ of hot water preparing needs, i.e. $3.0 \mathrm{TWh} / \mathrm{a}$.

Total annual heat losses in residential sector are huge in Lithuania. Preliminary estimate shows that use of passive solar space heating systems in case of favorable building location and orientation can reduce energy consumption by $20 \%$. Besides, such passive solar heating systems can be used for water heating and technological needs.

\section{Solar resources in Lithuania}

Solar energy - energy achieved from solar radiation defines Earth climate and maintains life. Solar light and heat are considered as renewable energy source however, technologies are still not adopted for efficient use of this source. The most modern technologies establish new opportunities for utilizing significant volumes of solar energy. Comparing to global trends Lithuania does not use solar energy vastly, though common interest is constantly growing. Public opinion dominates that solar collectors or PV can't operate efficiently due to lack of intensive solar radiation. However solar radiation data suggest that Lithuania is not much worse comparing to neighboring countries in this respect (Fig. 1).

For comparison the level of annual solar radiation: Norway $-780 \mathrm{kWh} / \mathrm{m}^{2}$, Sweden $-820-1050 \mathrm{kWh} / \mathrm{m}^{2}$, Lithuania $1001 \mathrm{kWh} / \mathrm{m}^{2}$, Czech Republic $-1030 \mathrm{kWh} / \mathrm{m}^{2}$, Germany $-1400-1650 \mathrm{kWh} / \mathrm{m}^{2}$, Italy $-1530 \mathrm{kWh} / \mathrm{m}^{2}$ per year. Solar radiation energy reaching the horizontal surface varies from $926 \mathrm{kWh} / \mathrm{m}^{2}$ in Biržai to $1042 \mathrm{kWh} / \mathrm{m}^{2}$ in Nida. In average this energy makes approximately $1000 \mathrm{kWh} / \mathrm{m}^{2}$ per year. Thus, annual volume of solar energy reaching country's area is $6.54 \cdot 10^{13} \mathrm{kWh} / \mathrm{a}$. 


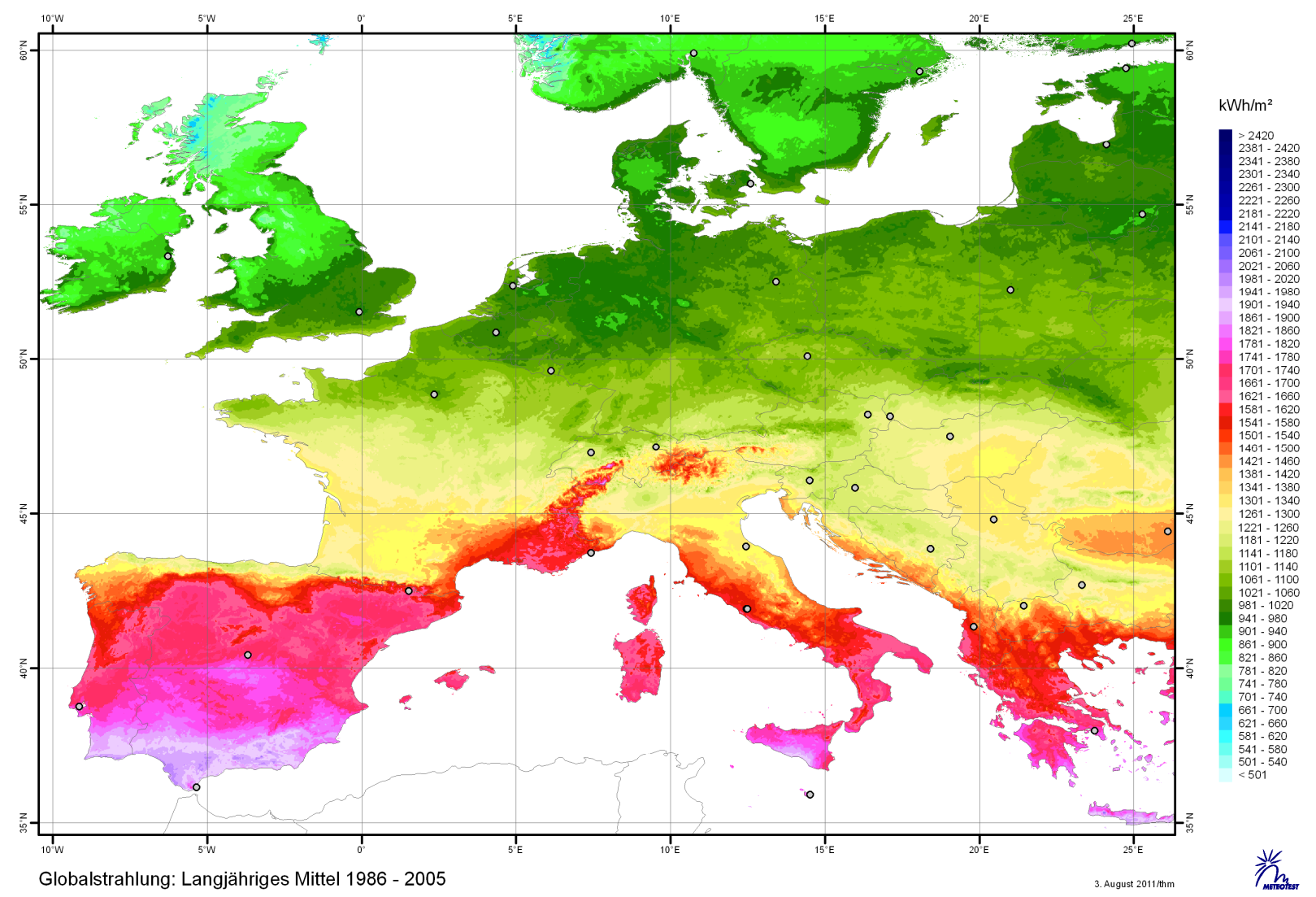

Fig. 1. The map of European solar energy potential [15]

The largest volumes of solar energy are in the South-West region of Lithuania, which provides the highest potential. The duration of sunshine, measured throughout eleven stations in Lithuania, depends on the distance from the sea mainly and differs by 250 hours, even the distance from the coast to the eastern border is not more, than $350 \mathrm{~km}$. Average yearly solar radiation on the horizontal surface is $968 \mathrm{kWh} / \mathrm{m}^{2}$ in Šilute and $1025 \mathrm{kWh} / \mathrm{m}^{2}$ in Kaunas, where the measurements of the solar radiation have been provided for the 45 years since the 1955 . Monthly distribution of total solar radiation in Kaunas (see Fig. 2) shows the very big difference between summer and winter, as Lithuania is rather far to the North. The largest part, $87.6 \%\left(910 \mathrm{kWh} / \mathrm{m}^{2}\right)$ of the yearly solar energy we get in March - September, so the first step to commercialization could be seasonal solar heating systems. Approximately only $190 \mathrm{kWh} / \mathrm{m}^{2}$ of solar radiation comes in winter season.

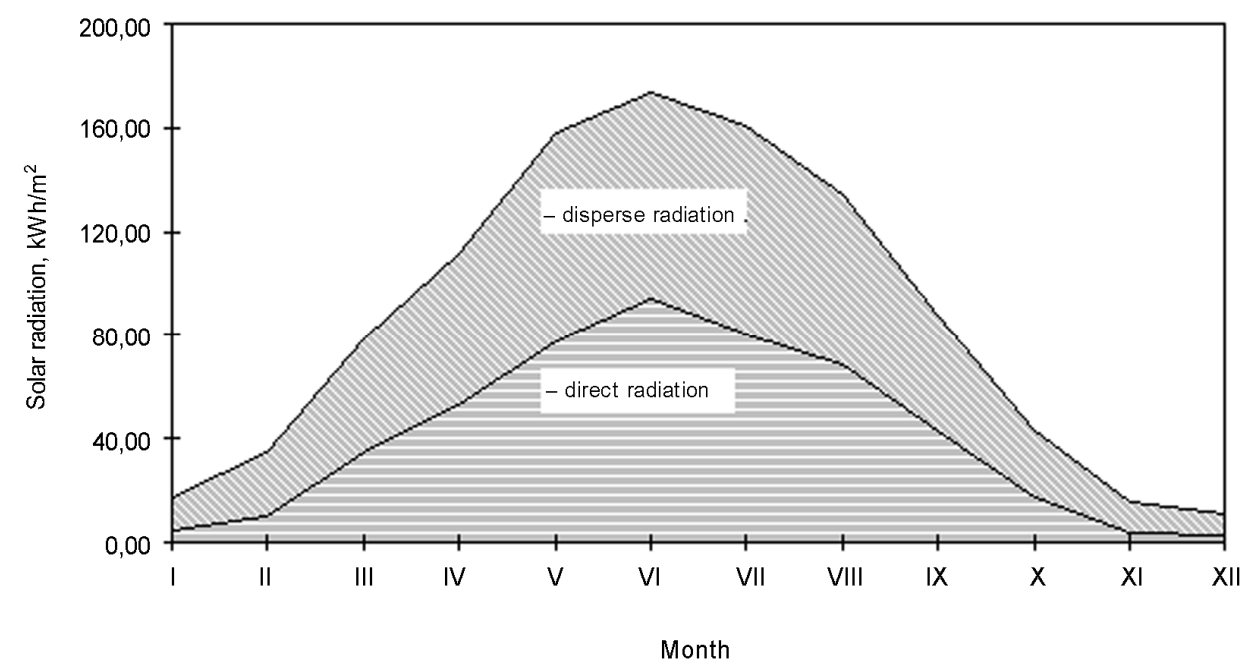

Fig. 2. The sums of the medium direct and disperse radiation onto the horizontal surface in Kaunas (medium cloudiness) [16]

Thus the volume of solar energy available during cold winter period is scare and in practice it could be used as the source of supplementary heat for existing heating system. In reality this solar energy could be used in solar collectors for water heating or premises heating needs via solar space heating systems. 


\section{Solar heating systems and technologies}

In general solar district heating systems consist of large collector fields integrated into a district heating system for supplying heat to residential and industrial areas. In practice this integration is realized in rather different ways under quite varying boundary conditions. Main aspects for distinguishing solar district heating systems are [17]:

Central district heating (DH) systems. In a central solar district heating system the solar thermal system feeds in at the main heating plant of the DH system. The collector field is typically ground mounted in close connection to the heating plant. Alternatively, the collectors can be mounted on building's roof and the heat is transferred to the heating plant via collecting grid. A large long - term storage connected to the heating plant enables high solar fractions. The plant is typically owned and operated by the owner of the district heating system e.g. the local utility.

Smaller central solar district heating plants are called solar block heating plants. Several such plants were built in Germany, often applied in new residential areas in combination with heating plants (without CHP). Eleven of these systems were designed for a solar fraction of $\sim 50 \%$ of the total heat demand and large seasonal heat stores were applied.

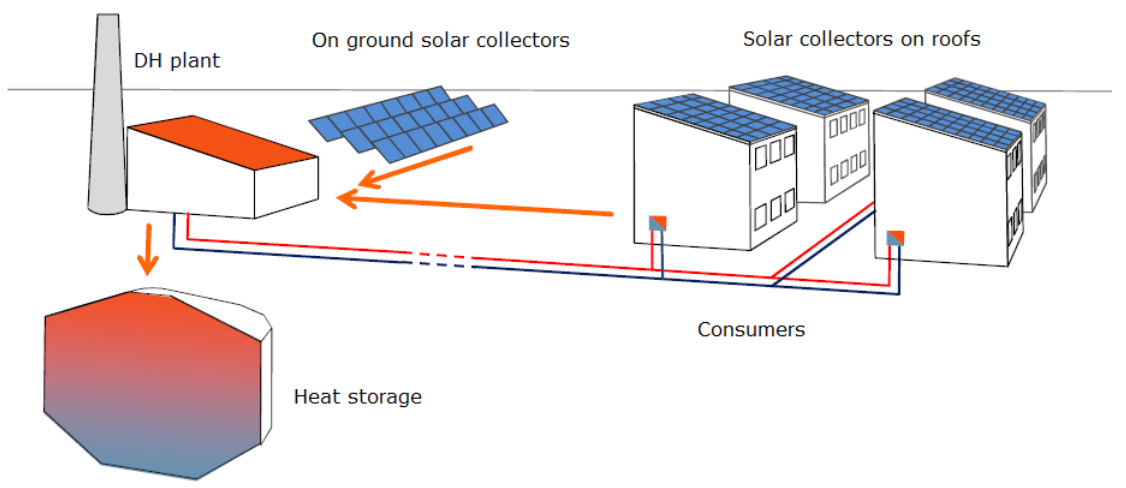

Fig. 3. Central solar district heating system. (Source: Solites [14])

Distributed systems. In distributed solar district heating plants the solar collector fields are installed at suitable locations at any place of the district heating network and connected directly to the district heating primary circuit on site. Often these plants utilize the district heating network as storage (as long as they provide a minor amount of heat in comparison to the total load in the district heating system). Systems realized so far are owned and managed either by a housing company or by an energy service company (ESCO) or by the district heat supplier.

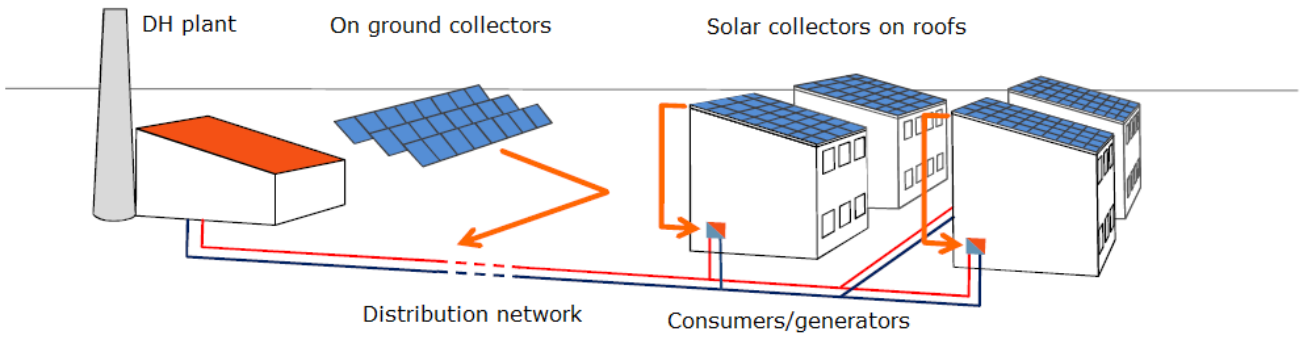

Fig. 4. Distributed solar district heating system. (Source: Solites [14])

Distributed solar block heating plants are realised e.g. in Sweden. In recent plants net-metering is applied, i.e. the collector fields are owned by the building owner who trades the solar heat according to a net metering contract with the district heating net owner as it is known from the grid-connected PV plants.

As the majority of solar irradiation in most regions is not during heating season, summer time operation is crucial for economics of a solar thermal plant. Heat demand (9-15h) in the feed-in area (to be examined for summer days, when no room heating is required):

- Domestic hot water consumption in supplied buildings,

- Hot water consumption of large consumers (industry, hospitals etc.); to be checked also for weekends and holidays,

- Circulation losses in supplied buildings,

- Heat losses in district heating grid (can be significant in summer months),

- If possible, using the district heating grid as heat storage.

When using the district heating grid as heat storage, also the return flow heats up during plant operation. For effective and safe solar plant operation, return temperature should be as low as possible. Thus when heating up the DH grid, return temperature should be as low as possible in the morning before start of feed-in from solar plant [18]. 
The yield of the solar plant decreases when return temperature rises. This is important in late afternoon, when return temperature increases and irradiation decreases. In this case the solar plant has to be switched off earlier in the afternoon than with constant return temperature. The resulting loss of operation time impairs the economics of the solar plant. For evaluating the heat demand between 9 and 15 o'clock in summer months in a certain part of the heating grid, a profound analysis is necessary and in most cases also measurements on heat demand, flow volumes and temperature levels.

In winter months, the minimum feed-in temperature of the flow can go beyond 90 or $100{ }^{\circ} \mathrm{C}$, depending on the operation parameters determined by the DH grid operator. It is possible to generate these temperatures with solar thermal also in winter. For economic and technical reasons, maximum temperatures of 60 to $80^{\circ} \mathrm{C}$ are more favorable for winter time operations of a solar thermal plant. If heat can't be fed in at these temperatures to the grid, the solar plant can supply other buildings directly. As heat demand is mainly early in the morning, heat storage needs to be integrated. Also a heat pump can be integrated in the solar circuit or the heat storage for increasing the efficiency at low temperature operation time.

For increasing the flexibility in operation of the solar plant, heat storage can be useful. The heat storage should be used both for the solar thermal plant and for load management of the DH grid. It is hardly feasible to finance large heat storage by solar-only use.

For maintenance and installation work at the district heating grid, shut-off of a branch of the grid might be needed for some hours. Shut-off should be done at times, when no feed-in from the solar plant is planned i.e. when there is enough capacity for charging the buffer tank or, even better, in hours when there is no solar irradiation on the collector field. Otherwise unplanned shut-off of the district heating grid might cause stagnation in the solar system.

Solar collectors. The most common collector types are evacuated tubular collectors (ETC) and flat plate collectors (FPC) without vacuum. Concentrating collectors may also be used, but since a large part of the annual irradiation is diffuse - especially in the northern part of Europe - and these types do not utilize the diffuse part. The choice of collector type depends on several factors such as:

- Price,

- Efficiency,

- Operating temperature,

- Location (available solar radiation, ambient temperatures).

In most of the large systems flat plate collectors are used. One advantage of FPCs is that they are made in larger units compared to ETCs. The most commonly used collectors for large SDH plants in Denmark have an aperture area of 13$14 \mathrm{~m}^{2}$. Larger units mean a lower number of pipes connecting the collector units which normally contributes significantly to the pressure losses. Another reason for the larger amount of FPC in SDH is that the durability of ETCs so far has not been proved in large SDH systems.

In most SDH systems a mixture of water and glycol is used as the collector fluid. This lowers the freezing point and the amount of antifreeze is determined by the minimum ambient temperature of the given location [19-23].

Storages. When heat from solar collector fields is integrated into a district heating network thermal energy storage is necessary. The main reason is that the storage enables to cope with the deviating solar heat production during the course of one day, several days or even of a season. So the surplus heat supply during high solar irradiation can be stored for heat demand phases with low solar fraction e.g. during the night or winter time. This increases the solar contribution to the system. At the same time the thermal energy storage helps to balance the demand of varying heat capacity rates. Furthermore, the storage of thermal energy decouples the supply of electricity from the supply of heat. This is of importance when e.g. CHP plants are integrated into district heating networks.

There are three applications of thermal energy storage:

1. Buffer storage for short term energy storage,

2. Large scale thermal energy storage $\left(1,000-50,000 \mathrm{~m}^{3}\right)$ for long term / seasonal thermal energy storage,

3. Large scale thermal energy storage for multiple usages (e.g. solar heat and waste heat).

Four main types of large-scale or seasonal thermal energy storages are used worldwide. The four storage concepts shown in Figure 5 include tank and pit thermal energy storage (TTES and PTES), borehole thermal energy storage (BTES) and aquifer thermal energy storage (ATES). New advanced storage techniques are phase change materials (PCM), thermo chemical storages and sorption storages. These techniques are not yet ready for the use in seasonal thermal energy storage applications. For more details see [24].

For TTES and PTES types due to the size and geometry and also due to the requirements in terms of leakage detection and lifetime most techniques and materials have their origin in landfill construction. However, with respect to high operation temperature materials and techniques cannot be simply transferred. Dimensions of pilot and research tank thermal energy storages and pit thermal energy storages that have been realized over the last 25 years for solar assisted district heating systems, range from several $100 \mathrm{~m}^{3}$ up to $75000 \mathrm{~m}^{3}[24,25]$.

For BTES and ATES types underground thermal energy storage systems can be divided into two groups [26]:

- Systems where a technical fluid (water in most cases) is pumped through heat exchangers in the ground, also called "closed" systems (BTES),

- Systems where groundwater is pumped out of the ground and injected into the ground by the use of wells, also known as "open" systems (ATES). 
Tank Thermal Energy Storage (TTES)

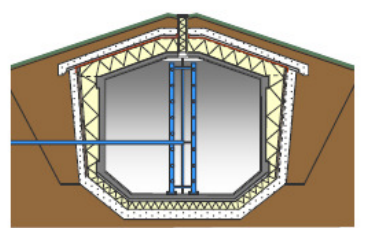

Borehole Thermal Energy Storages (BTES)

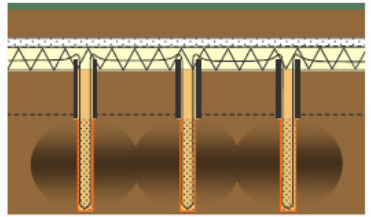

Pit Thermal Energy Storage (PTES)

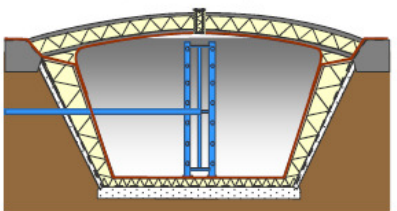

Aquifer Thermal Energy Storages (ATES)

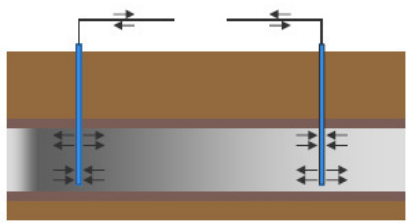

Fig. 5. Construction concepts for large-scale or seasonal thermal energy storages (Source: Solites [14])

An advantage of closed systems is the independency from aquifers and water chemistry, an advantage of open systems is the generally higher heat transfer capacity of water well compared to a borehole. This makes ATES usually the cheapest alternative, if the subsurface is hydrogeologically and hydrochemically suitable.

For the choice of a suitable storage concept for a specific plant all relevant boundary conditions have to be taken into account: local geological situation, system integration, required size of the storage, temperature levels, power rates, number of storage cycles per year, legal restrictions etc. Finally, decisions should be based on an economic optimisation of the different possibilities.

\section{The environment for the solar heat systems}

The main national legislation having focus on energy efficiency in buildings and support measures for district heating and solar thermal is the Directive on the Energy performance of Buildings, which was implemented under Law on Construction of the Republic of Lithuania. This law defined energy performance certification, adoption of methodology for assessment of energy performance in buildings, setting minimum energy performance requirements, nearly zero-energy buildings.

Another Law on Energy from Renewable Sources implementing Directive of the European Parliament and of the Council on the promotion of the use of energy from renewable sources passed Parliament. According to this law Ministry of Energy coordinates implementation and promotion measures for the use of solar heat for energy generation, carries out monitoring of their implementation, and provides state supervision and control. The law requires certification for installers of solar heat and power generating equipment using renewable energy.

Support schemes for solar heat installations are applied, in case they are certified in accordance with European standards, in case these are defined, including ecological labelling, energy labelling and others technical regulation systems defined by EU standardization bodies. The National Renewable Energy Action Plan must submit assessment regarding development of the new district heating and cooling infrastructure with providing conditions for development of biomass, solar and geothermal plants for achieving respective RES indicators till year 2020. The Government or its' authorized institution shall prepare and adopt program for the use of building roofs for energy generation using solar thermal and solar PV installations. Solar thermal collectors and heat pumps do not apply to land-use compliance requirements, environmental impact assessment procedure and do not need authorization for construction and impact of vi-societal health assessment.

All new buildings have to meet energy requirements of A energy efficiency class after 1 January 2016. Modernization of public, industrial buildings and residential houses should consider the possibility to use installations for electricity, heat and cooling generation from renewable sources. The type of renewable source is not specified by the law.

Building meets requirements of A++ energy efficiency class (nearly zero-energy building) if ratio between renewable and non-renewable energy in the building is more than one. Nearly-zero energy buildings need much less heat for space heating which can be supplied using existing network and lower heat carrier temperatures. DH companies are interested in heat losses reduction in networks and reduced temperature of heat carrier means lower heat losses in networks. This is seen as opportunity for district heating companies and solar heating.

Up to 50-70\% energy share from renewable sources in district heating is to be achieved until 2020. However, there are no specific provisions for solar heat. The growth of RES share is foreseen mainly on the account of biomass.

Expansion of district heating in Lithuania is limited due to market saturation. District heating companies cover between $60 \%$ and $90 \%$ of heating market in the largest cities in Lithuania. New wood biomass boilers or CHP plants are installed in reconstructed boiler-houses for base load operation during all the year. Usually, these reconstructions are implemented with EU support. New installations, such as solar collectors, will require additional investment which is challenge for district heating companies. Majority of buildings consume a big amount of heat during heating season. Lower heat sales mean less revenues for district heating companies in case of consumers solar installations. 


\section{Economic evaluation of solar DH}

At first stage screening of Lithuanian DH companies was performed with the aim to select DH systems that best suits for the purpose of this investigation. The criteria for selecting of suitable DH companies/networks for possible solar heating installations were:

- Scale of DH system - smaller systems are more flexible and in most cases have higher heat losses in networks,

- Fuels and technology used - systems with bio-cogeneration units were excluded, usage of fossil fuels create stronger motivation for introducing renewable sources,

- Location of DH system - easier to find necessary land area for solar collectors in or nearby small cities.

Seventeen small DH systems were selected for analysis in this investigation. Total annual heat demand in the DH systems vary from 20 to $71 \mathrm{GWh}$, and from 2 to $6.5 \mathrm{GWh}$ of this amount falls to hot water preparing and temperature maintaining in building's hot water systems. In addition, heat losses in network should be taken into account, which are relatively higher comparing with average annual losses (Fig. 6).

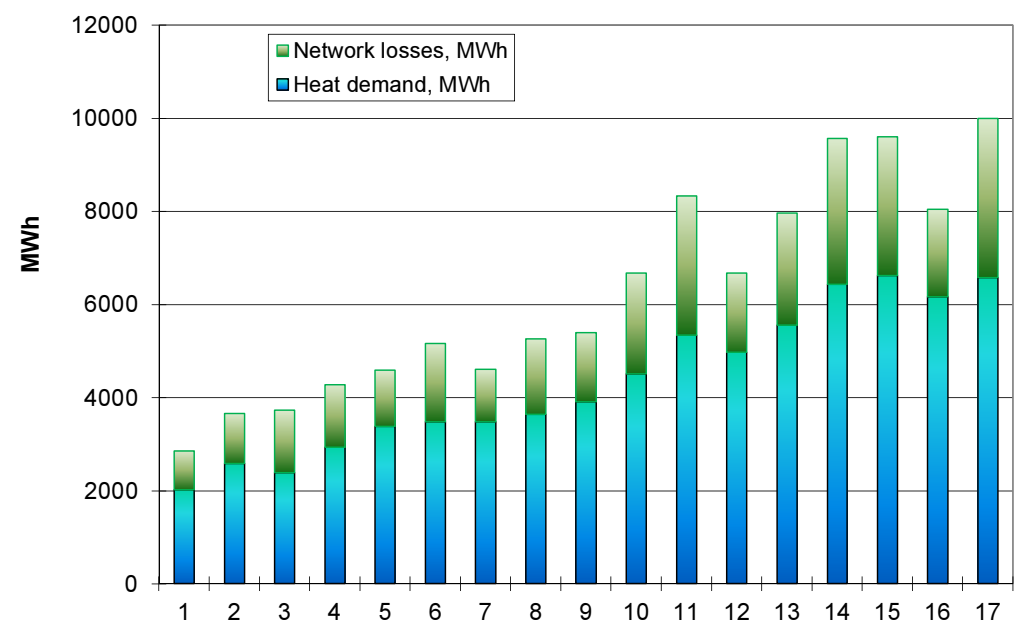

Fig. 6. Summer season (May - September) heat demand and network losses in analyzed DH systems

It is known that lowest heat generation costs in solar thermal systems are when its capacity is designed to satisfy hot water needs in summer time. Therefore, collector's area is calculated to produce monthly amounts of heat necessary for DHW systems and compensation of network losses. Required heat storage volume is based on heat demand for time intervals when solar collectors can't produce enough heat (night-time, big cloudiness).

The data for economic analysis were collected from DH companies and supported by real investment values obtained from SDHplus partners. General scheme for economic evaluation is presented in Figure 7.

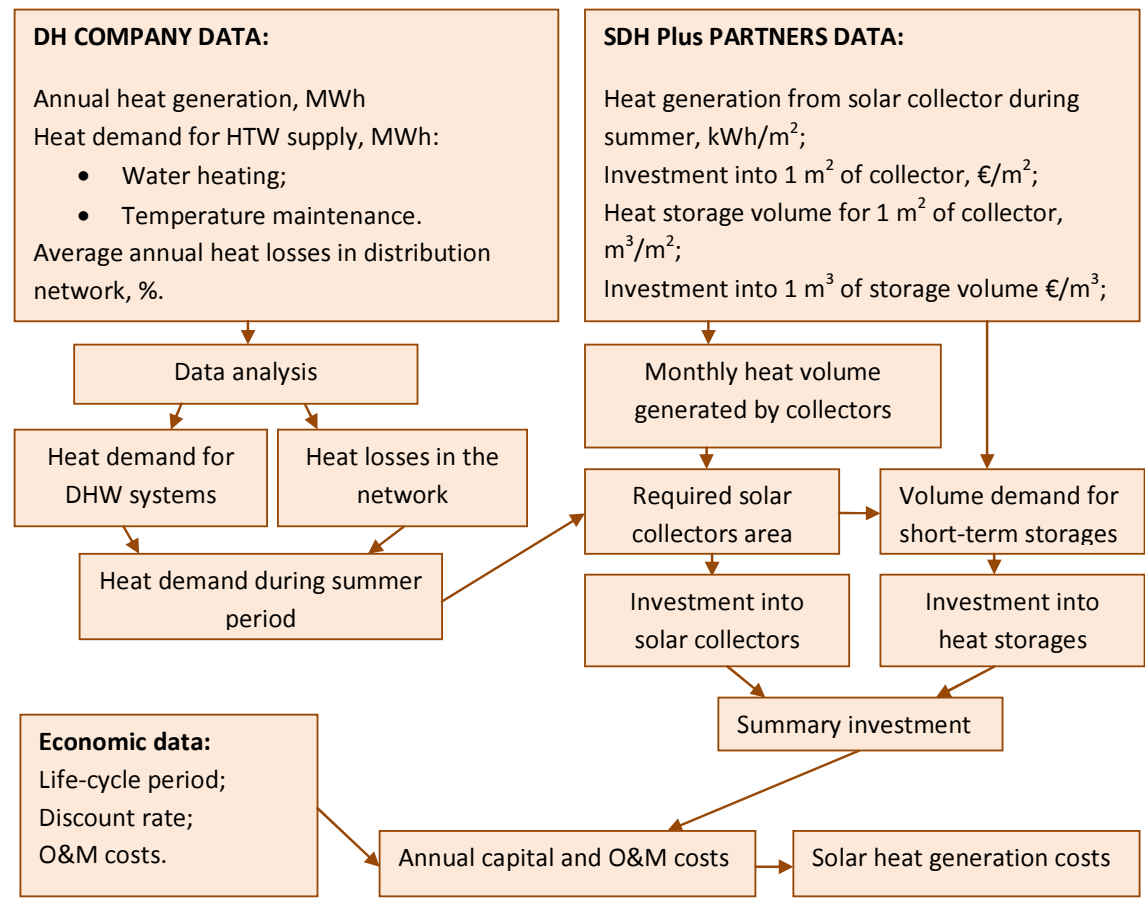

Fig. 7. Scheme for economic analysis 
Table 1. Main economic values used in the investigation

\begin{tabular}{llll}
\hline No. & Name & Unit & Value \\
\hline 1 & Discount rate for investment & $\%$ & 6 \\
\hline 2 & Life-time of installation & years & 20 \\
\hline 3 & Investment into solar collectors & $€ / \mathrm{m}^{2}$ & 200 \\
\hline 4 & Investment into short-term heat storage & $€ / \mathrm{m}^{3}$ & 130 \\
\hline 5 & Annual O\&M costs & $\%$ of total investment & 1 \\
\hline
\end{tabular}

The main economic figures used in the investigation are presented in Table 1. Land value is not included into calculation because of uncertainties in land price and ownership.

Values used in the analysis are average figures and can vary significantly depending from construction site, equipment producer, heat storage type, necessary civil works, and connection to the network. Nevertheless, this indicative analysis can provide general information on competitiveness of solar heating technology.

The four scenarios were estimated in economic analysis - without support for investment and with $30 \%, 50 \%$ and $75 \%$ investment subsidy. Calculated heat production cost is compared with present heat price in corresponding DH system by adding average distribution cost, which was found approximately equal to $14 € / \mathrm{MWh}$. The calculation results demonstrate that solar heat can be competitive in some DH companies having highest heat prices even without support. Those are using natural gas or liquid fuel. However for most companies using biofuel, solar energy can't reduce heat cost if there is no support for investment (Fig. 8).

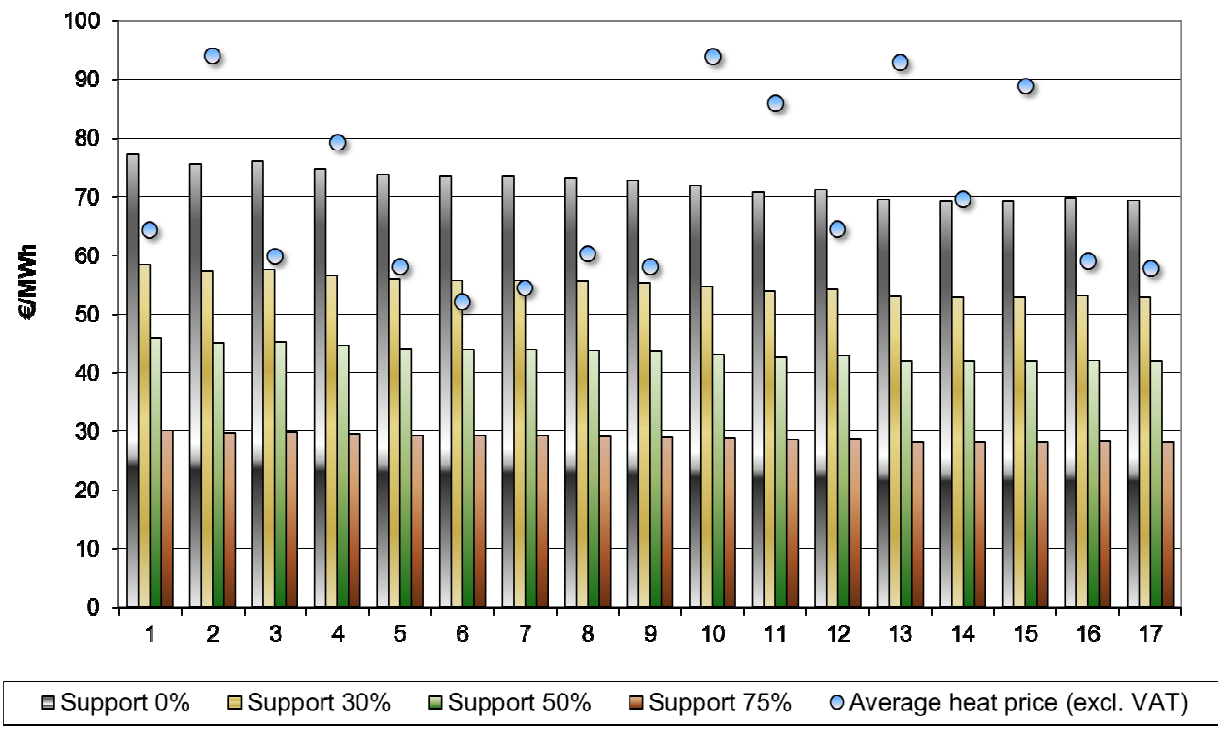

Fig. 8. Solar heat cost depending of intensity of support for investment

Even 30\% subsidy can improve competitiveness of solar heating significantly. Higher support can provide opportunities for larger share of solar heat in DH system, as larger solar collector area and storage volume can be installed. Optimization of investment with regard to support intensity and local peculiarities is necessary for each single DH system

It is notable, that solar heat cost is independent from fuel price fluctuations. This can be regarded as advantage having in mind growing biomass price as well as oil and gas prices.

\section{Conclusions}

An analysis of experience using solar heating in DH systems proves solar heating as viable alternative to biomass fuel and supplements it. This is very actual issue when local resources are scared. Besides, such issues as noise, fumes, and air pollution from biofuel transportation and burning should be taken into account.

An essential issue for solar heating technology penetration into existing heat production market is legal basis and support measures creating equal and non-discriminating market conditions for all alternative energy resources.

Minimal 30\% support for investment would make SDH an attractive alternative to biofuel and enable to cover approximately $10-12 \%$ of annual heat demand. Larger share of solar heat can also be achieved with higher support intensity.

Installations already in operation demonstrates that higher share of solar heat in DH system (up to 50\%) can be reached using seasonal heat storage; however, this is related to significant increase of investment, resulting higher heat cost. 


\section{Acknowledgements}

The authors would like to express their acknowledgements to their partners in project "Solar District Heating" (SDH plus), partly funded by EU Programme Intelligent Energy for Europe, which was launched to foster development of solar heat in district heating systems.

\section{References}

[1] Strategic Plan for the IEA Solar Heating \& Cooling Programme 2014-2018. 2004. P. 34. Website: http://www.iea-shc.org/strategic-plan.

[2] Jablonski, S.; Tarhini, M.; Touati, M.; Gonzalez Garcia, D.; Alario, J. 2012. The Mediterranean Solar Plan: Project proposals for renewable energy in the Mediterranean Partner Countries region, Energy Policy 44 : 291-300. http://dx.doi.org/10.1016/j.enpol.2012.01.052

[3] Thiers, S.; Peuportier, B. 2012. Energy and environmental assessment of two high energy performance residential buildings, Building and Environment 51: 276-284. http://dx.doi.org/10.1016/j.buildenv.2011.11.018

[4] Sperling, K.; Möller. B. 2012. End-use energy savings and district heating expansion in a local renewable energy system - A short-term perspective, Applied Energy 92: 831-842. http://dx.doi.org/10.1016/j.apenergy.2011.08.040

[5] Technology Roadmap. Solar Heating and Cooling. International Energy Agency. OECD/IEA, 2012. P. 50.

[6] Lund, H.; Moller, B.; Mathiesen, B. V.; Dyrelund, A. 2010. The role of district heating in future renewable energy systems, Energy 35: $1381-1390$. http://dx.doi.org/10.1016/j.energy.2009.11.023

[7] Li, Y.; Fu, L.; Zhang, Sh.; Zhao, X. 2011. A new type of district heating system based on distributed absorption heat pumps, Energy 36: $4570-4576$. http://dx.doi.org/10.1016/j.energy.2011.03.019

[8] Sanaei, S.; M.; Nakata, T. 2012. Optimum design of district heating: Application of a novel methodology for improved design of community scale integrated energy systems, Energy 38: 190-204. http://dx.doi.org/10.1016/j.energy.2011.12.016

[9] Hassine, I. B.; Eicker, U. 2013. Impact of load structure variation and solar thermal energy integration on an existing district heating network, Applied Thermal Engineering 50: 1437-1446. http://dx.doi.org/10.1016/j.applthermaleng.2011.12.037

[10] Nielsen, J. E. 2012. IEA-SHC Task 45: Large solar heating/cooling systems, seasonal storage, heat pumps, Energy Procedia 30: 849-855. http://dx.doi.org/10.1016/j.egypro.2012.11.096

[11] Mathiesen, B. V.; Lund, H.; Connolly, D. 2012. Limiting biomass consumption for heating in 100\% renewable energy systems, Energy 48: 160-168. http://dx.doi.org/10.1016/j.energy.2012.07.063

[12] Connor, P.; Burger, V.; Beurskens, L.; Ericsson, K.; Egger, Ch. 2013. Devising renewable heat policy: Overview of support options, Energy Policy 59: 3-16. http://dx.doi.org/10.1016/j.enpol.2012.09.052

[13] Nast, M. 2010. Renewable energies heat act and government grants in Germany, Renewable Energy 35: $1852-1856$. http://dx.doi.org/10.1016/j.renene.2010.01.011

[14] Solar District Heating Guidelines. Collection of Fact Sheets. Deliverable of SDHplus (Solar District Heating) project under "Intelligent Energy for Europe programme". August 2012. Website: http://www.solar-district-heating.eu/.

[15] Solar Irradiation maps by Meteotest. Website: http://www.meteotest.ch/en/business fields/solar energy/datamaps/.

[16] Solar energy usage in Lithuania. ENERGIE OPET LITHUANIA. Represented by LEI. Website: http://www.lei.lt/Opet/Res/solar_energy.htm.

[17] Dalenbäck, J.-O. 2010. Success Factors in Solar District Heating, www.solar-district-heating.eu.

[18] Streicher, W.; Fink, Ch. 2006. Einspeisung von Solaranlagen in (bestehende) FW-Netze, Gleisdorf Solar.

[19] Technical guide - Solar thermal systems, 2009. Viessmann GmbH.

[20]Fan, J.; Furbo, S. 2008. Buoyancy Effects on Thermal Behavior of a Flat-Plate Solar Collector, Dep. of Civil Engineering - Technical University of Denmark. www.aseanenergy.info/Abstract/31029901.pdf

[21]Fan, J.; Furbo, S. 2007. Optimering og afprøvning af solfanger til solvarmecentraler (Optimization and testing of solar collector for SDH plants), Dep. of Civil Engineering - Technical University of Denmark. www.byg.dtu.dk/upload/institutter/byg/publications/rapporter/byg-sr0706.pdf

[22] Furbo, S., et al. 2009. Levetid for solfangere i solvarmecentraler (Lifetime for collectors in SDH plants). Dep. of Civil Engineering - Technical University of Denmark, 2009, www.byg.dtu.dk/upload/institutter/byg/publications/rapporter/byg-r210.pdf

[23]Data sheet for Sunmark solar collector. www.sunmark.dk/files/14m2-dk-140D.pdf

[24] High solar fraction heating and cooling systems with combination of innovative components and methods.

[25] Schmidt, T., Mangold, D., Sørensen, P.A., From, N. 2011, Large-scale heat storage, IRES 2011 6th International Renewable Energy Storage Conference, Eurosolar, Berlin, Germany

[26] Sanner, B. 2001. A different approach to shallow geothermal energy - Underground Thermal Energy Storage (UTES), International Summer School on Direct Application of Geothermal Energy. Skopje, Bad Urach, Germany 